\title{
Socio-Economic Analysis and Strategies of Sustainable Rural Development in Romania
}

\begin{tabular}{l}
\hline \multicolumn{1}{c}{ A R T I C L E I N F O } \\
\hline Article history: \\
Accepted November 2020 \\
Available online December 2020 \\
\hline JEL Classification \\
Q01, Q13, Q18, 013, 018 \\
Keywords: \\
Rural area, Agriculture, Sustainable \\
Rural development
\end{tabular}

Alina Florentina Saracu ${ }^{\star}$, Maria Smochina ${ }^{\star \star}$

A B S T R A C T
The study of this article intends to study the performances in sustainable rural development in Romania with focus on the main fields in the rural sector, between 20142018. Using the econometric tool, we prove the dynamics of sustainable rural development on economic growth in Romania, so as to subsequently demonstrate which are the most effective strategies meant to stimulate the development of this sector. Therefore, sustainable rural development is the motion with the purpose to progress and endow the region, without achieving urban expansion, while preserving the traditional specificity of rural culture. The progress of this sector is a significant component in the modernization of the state economy, contributing to its proper functioning based on the market economy principles. This process contributes to increasing the level of agri-food production, the complex improvement of the national economy, as well as to the sustainable growth of the regions or the resolution of social dilemmas.

(C) 2020 EAI. All rights reserved.

\section{Introduction}

In the modern economy, the rural sector has progressed continuously and speeded up in global significance, in parallel with growth off the value and weight of this phenomenon which has intensified at such a fast pace, that it has come to concur to the execution of a significant share of the GDP world.[15] International practice has shown that rural area is one of the major challenges of the future through its responsibilities and implications for the entire economic system. For the purpose of recording a much higher economic growth, it should be paid greater attention to the sustainable development of this sector.

Sustainable rural development, in the circumstances of the current stage of the world economy and the environment, is a vast and very complex issue. It is an inseparable term related to the aspect of continuity, being in a continuous process of adaptation to the conditions of the reality specific to agriculture, which makes possible a transition from an agricultural (sectoral) policy toward an integrated approach to rural development.

The strategic directions of development in the sector of rural sustainable development with impact in the economic development of Romania are based on the change of the guideline from the growth model based on consumption fueled by remittance to a dynamic model based on attracting foreign and local investments, as well as the development of industries exporting goods and services in the rural sector. Specifically, modernization for sustainable rural development is envisaged in three main dimensions: economic growth, social equity and environmental protection.

This paper intends to provide a clear image of the effects resulted from the rural sector enterprises operating in Romania and who may be a starting point for grounding the strategies that desired outcomes: achieving better productivity and greater efficiency high. It targets to set up a research on the progress of the Romanian rural region summing up all aspects: economic, social, ecological, etc., with a highlight on the general ideas of rural development in the clause of sustainability and multifunctionality. In this situation, we specify that Romania is placed in the list of countries that implement the European model of agriculture sector and rural development.

\section{General socio-economic situation in the rural area in Romania}

Rural areas have a significant growth potential and a vital social mission. Out of the total area of Romania, the rural areas consisting in townships, as territorial administrative units, together with the component villages (as defined in the national legislation) [2] is approximately 87.1\%.[7] In correspondence 
with the presented notion, we specify that the surface of Romania provides: 59.8\% rural, 39.4\% intermediate, $0.8 \%$ urban. [8]

In 2018, within rural areas, it was recorded $45.8 \%$ of the population in the country. During the period 2014-2018, there was an increase of $0.6 \%$ in the number of people in rural areas, which arose following a reduction of child births and migration.

Table 1. Population in rural areas over the years 2014-2018 (\%)

\begin{tabular}{|c|c|c|c|c|c|}
\hline Year & $\mathbf{2 0 1 4}$ & $\mathbf{2 0 1 5}$ & $\mathbf{2 0 1 6}$ & $\mathbf{2 0 1 7}$ & $\mathbf{2 0 1 8}$ \\
\hline Population in rural area (\%) & $43.6 \%$ & $46.2 \%$ & $46,1 \%$ & $46 \%$ & $45.8 \%$ \\
\hline
\end{tabular}

The population from rural areas in Romania is irregularly distributed. Thus, according to the "Opinion for the National Rural Development Program 2014-2020", drawn up by the Ministry of Environment, Waters and Forests, the highest density (excluding the Bucharest-Ilfov region with $20 \%$ of the rural population) is registered in the North-East area (63.24 inhabitants $/ \mathrm{km}^{2}$ ), while in the western area, the rural area means a much lower density $\left(26,51\right.$ inhabitants $\left./ \mathrm{km}^{2}\right)$. [9] This lack of proportionality marks deeply the socio-economic development of the region and the quality level of life of the rural inhabitants. [15]

The phenomenon of population aging has not bypassed Romania either. The process of population aging was caused by the decrease in the birth rate and migration, which caused to be considered as young population those between the ages of 0-14 years, and the old people over 65 years.

Table 2. Average and median age in rural areas (2014-2018) (years)

\begin{tabular}{|c|c|c|c|c|c|}
\hline Year & $\mathbf{2 0 1 4}$ & $\mathbf{2 0 1 5}$ & $\mathbf{2 0 1 6}$ & $\mathbf{2 0 1 7}$ & $\mathbf{2 0 1 8}$ \\
\hline Average age in rural areas (years) & 41.4 & 41.5 & 40.6 & 41.9 & 42 \\
\hline Median age in rural areas (years) & 39.9 & 41.1 & 39.8 & 41.9 & 42.2 \\
\hline
\end{tabular}

Source: Drawn up by the author based on data provided by the National Institute of Statistics (2014-2018) [5]

Another alert regarding this phenomenon is that it has led to an increase in values for the average and median age of the inhabitants of Romania (during the years 2014-2018, in rural areas the average age increased by 1.4 years, and the median age went up by 1 year). The rural population, with an average age of 42.2 years, is more aged by 0.2 years. The median age is also higher in rural area than in urban areas, by 0.6 years. Thus, in 2018, half of the rural area in Romania was less than 42.5 years old.

According to european statistics, whorkforce in the field of agriculture ranks Romania on the first place in the UE. This is due to the large number of small farms or subsistence farms, as well as the fragmentation of agricultural land in Romania In point of long-term unemployment, there are recorded close values recorded by urban and rural areas. Compared to the European Union, where there are created technological farms, able to work large areas of agricultural land with a small number of employees, in Romania, it is the opposite - a very large number of farms, with relatively small areas, lacking technological equipment, where a large number of employees are needed to work this territory. [13]

A less enjoyable news is that, over the last years, the absence of measures to encourage people for working in agriculture and pushing forward the migration process, has led to a major labor shortage. Finally, in 2018 was estimated a decrease in the labor force from agricultural sector by about 7\%. [13] This discrepancy is due to the process of curtailing the labor force reserve, as well as from the viewpoint of age and education.

The unemployment rate by residential areas, rural area (4.7\%) represents a higher share of $0.9 \%$ compared to urban area (3.8\%). (43,2\% for rural areas and 45,0\% for urban areas). [6] The most affected area of unemployment is that of young people (15-24 years old), who cannot be employed according to the studied specialization.

The poverty rate in Romania is the highest in the European Union, although it has taken important measures to control it. According to Eurostat data, over $40 \%$ of the population are still exposed to the risk of poverty (the poverty in rural areas is 3 times higher than in urban areas). As stated above, more than $45 \%$ of the population of the country lives in rural areas, where the areas of poverty are absolute and social exclusion prevails.

Economic progress is based on investment and competitiveness. Romania, in order to be successful in an economic growth and to create a convergence of the revenues of the other european countrys, more attention should be paid to improving these elements. To the achievement of economic growth took part, together with the other branches of the national economy, the results of agriculture and food industry, even though an integrated analysis of global efficiency indicators shows that the agriculture of Romania has much higher potential as to the accomplishments by now, potential with which we can reach economic efficiency in the developed countries of the world.

The contribution of agriculture, forestry and fisheries to GDP (Table 3) has always been high, nevertheless, remaining low, considering the unused resources. Thus, in recent years, the contribution of 
agriculture, forestry and fisheries to the GDP formation has accounted for 3.48\%, and to GDP growth averaging $0.22 \%$. For Romania, this indicator proves a low level of productivity of the production factors and an unbalanced distribution of labor within the agricultural sector.

Table 3. The contribution of agriculture, forestry and fisheries to the formation and growth of GDP

\begin{tabular}{|c|c|c|c|c|c|c|c|c|c|c|}
\hline \multicolumn{11}{|c|}{$(2014-2018)(\%)$} \\
\hline & \multicolumn{2}{|c|}{2014} & \multicolumn{2}{|c|}{2015} & \multicolumn{2}{|c|}{2016} & \multicolumn{2}{|c|}{2017} & \multicolumn{2}{|c|}{2018} \\
\hline & $\begin{array}{l}\text { Contribution } \\
\text { to GDP } \\
\text { formation } \\
(\%) \\
\end{array}$ & $\begin{array}{c}\text { Contribution } \\
\text { to GDP } \\
\text { increase }(\%)\end{array}$ & $\begin{array}{l}\text { Contribution } \\
\text { to GDP } \\
\text { formation } \\
\text { PIB (\%) }\end{array}$ & $\begin{array}{l}\text { Contribution } \\
\text { to GDP } \\
\text { increase }(\%)\end{array}$ & $\begin{array}{l}\text { Contribution } \\
\text { to GDP } \\
\text { formation } \\
(\%)\end{array}$ & $\begin{array}{c}\text { Contribution } \\
\text { to GDP } \\
\text { increase }(\%)\end{array}$ & $\begin{array}{l}\text { Contribution } \\
\text { to GDP } \\
\text { formation } \\
(\%)\end{array}$ & $\begin{array}{l}\text { Contribution } \\
\text { to GDP } \\
\text { increase }(\%)\end{array}$ & \begin{tabular}{|c|} 
Contribution \\
to GDP \\
formation \\
$(\%)$ \\
\end{tabular} & $\begin{array}{l}\text { Contribution } \\
\text { to GDP } \\
\text { increase (\%) }\end{array}$ \\
\hline $\begin{array}{c}\text { Agriculture, } \\
\text { forestry and } \\
\text { fishery }\end{array}$ & 4.7 & 0.1 & 3.9 & 0 & 4.4 & 0.7 & 2.5 & 0.2 & 1.9 & 0.1 \\
\hline
\end{tabular}

As a result of the enhancement in the level of activity during $2014-2018$ period, as well as of the reduction of the materials consumption, against the background of the restructuring and modernization of the economy, the gross added value saw significant increases. Despite the good results and the positive influences of $0.2 \%$, the contribution of agriculture, forestry and fishery remained below $5 \%$.

Finally, analyzing the model of socio-economic growth of rural areas in Romania, we deduce that it affects the country's ability to record a continuous and consistent sustainable rural development in the European Union.

\section{Agriculture and rural sectors in Romania}

The rural economy of Romania, largely exploited by agriculture, is one of the most important branches of the Romanian economy. Although still poorly integrated into the market economy, it depends on the well-being of rural people and agricultural producers.

Romania has important land resources, with 0.68 ha per capita of agricultural land and 0.43 ha of arable land. [11] Out of the total area of the country (230170 $\mathrm{km}^{2}$ ) around $60 \%$ make up agricultural land. Although many regions of the agricultural land of the country are deemed to be underprivileged, pedological conditions are accessible to agricultural production activities, especially in the southern and western regions. By mode of use, the agricultural area includes: arable land (64.2\%) - most of the agricultural area, being followed by - pasturelands (22.4\%), hayfields (10.6\%), vineyards and orchards (2.8\%).[3]

In order to have the possibility to identify the main potentials and oppressions that confine the growth of the agri-food economy, it is required to analyze the competitiveness of the main agri-food fields in Romania. In the following, a summary of these aspects is presented on the main categories of agri-food products for which Romania meets natural and agropedalogic conditions favorable to achieving production and getting results comparable to those achieved by the European Union member states.

The structure of agricultural branch production (Figure 1) grew over the years researched. Overall, it increased in 2018 by $10.7 \%$ compared to 2014 . The vegetal production structure, during the research period, increased by $38.2 \%$. On the subject of the animal production structure, it increased, but not as significantly as those recorded by the structure of plant production. Specifically, the structure of animal production, in 2014-2018, increased by only $13.7 \%$, with a $24.5 \%$ difference compared to the plant production structure. Moreover, the agricultural service showed an increased weight in 2018 by $43.3 \%$, compared to the other years researched.

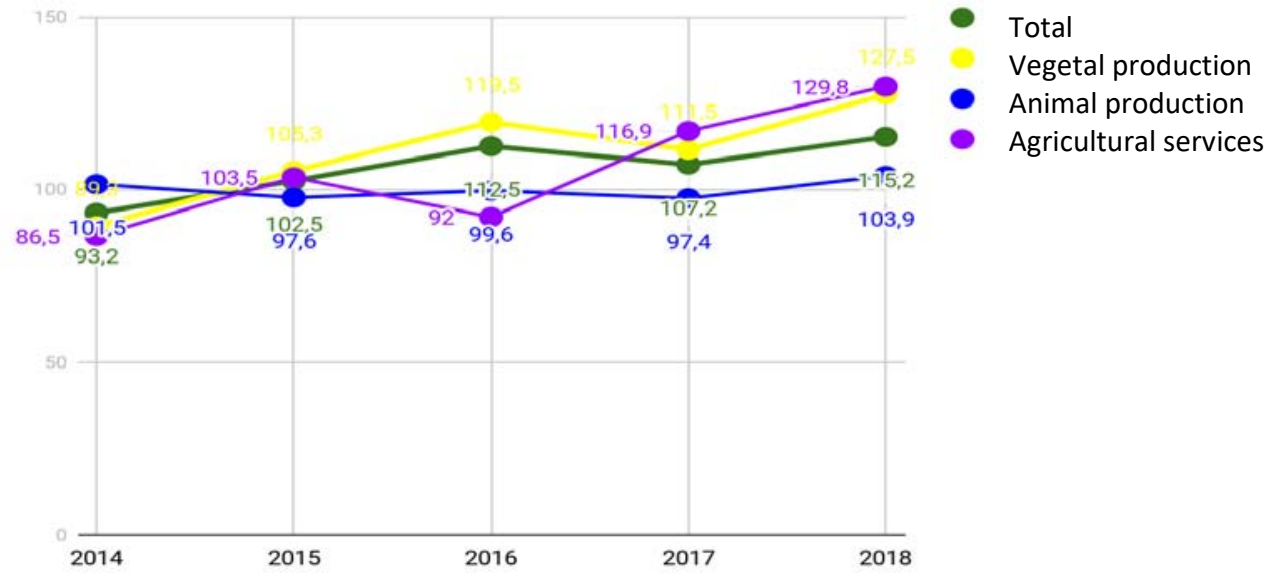

Figure 1. The structure of agricultural branch production (2014-2018) (\%)

Source: Prepared by authors based on data provided by the NIS (2014-2018) [3] 
The value structure of the vegetal production on the main groups of crops (Figure 2) did not register significant changes from a year to another, during the researched years.

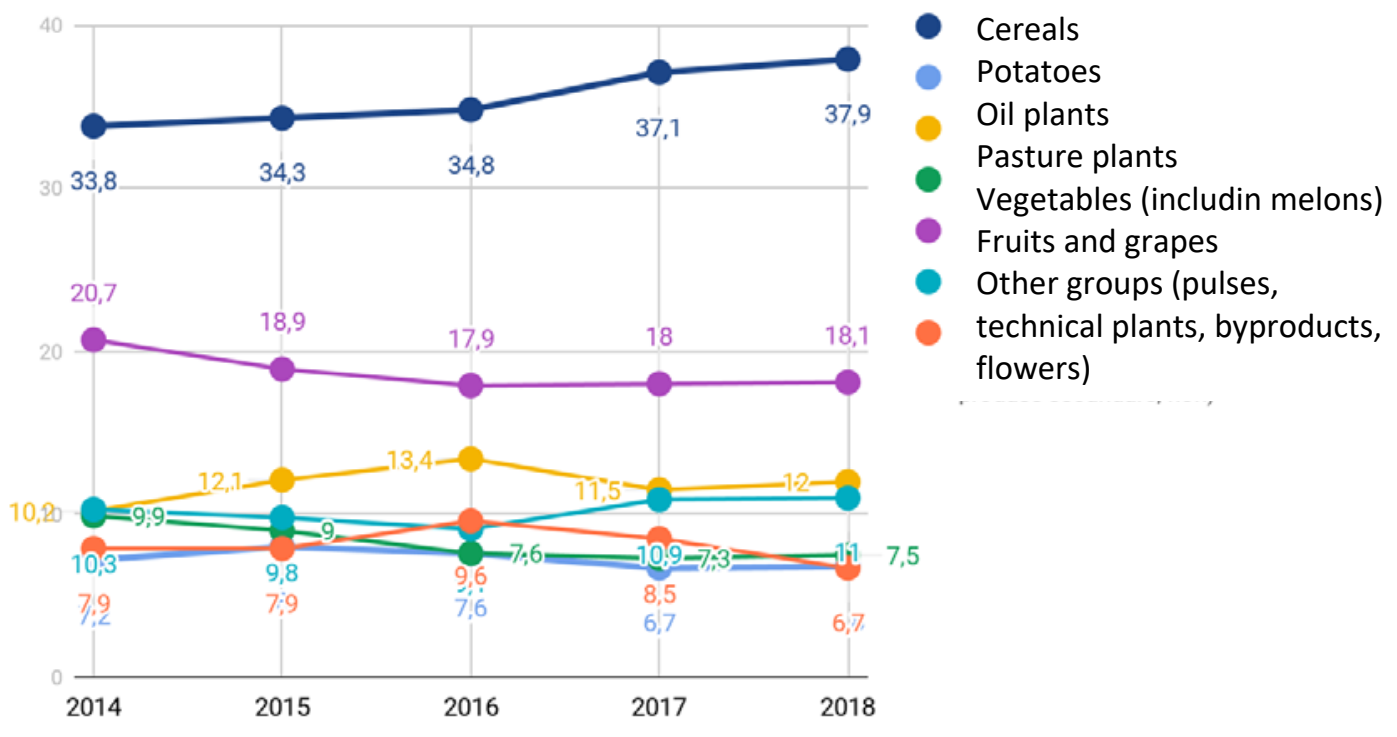

Figure 2. The value structure of the vegetal production on the main groups of crops (2014-2018) (\%) Source: Drafted by authors based on data provided by the NIS (2014-2019) [3]

Cereal crops have the highest value of production, with a value of over 30\%. During the research period, the weight of cereals went up yearly, with values between $0.5 \%-2.3 \%$. The second place in the top is held by the group of legumes crops, with approximate values of 18\%. Between 2014-2018, its weight decreased significantly, by about 2.6\% (the lowest value being recorded in $2016-17.9 \%$ ). The top is followed by oily plants, with a weight of about $12 \%$, then by the group of fruits and grapes - about $10 \%$, fodder plants around $9 \%$, potatoes - about $7 \%$, being concluded by other groups (pulses, technical plants, flowers, etc.) which constitute a little over $7 \%$.

Romania is considered a cereal force. The strengths of the cereals sector in Romania are the favorable soil conditions and climate, which enable the practice of various types of technologies and the cultivation of a wide range of crops. The total agricultural area is relatively large, ranking Romania among the first places in the European Union. The strategic position of Romania among the countries between the Middle East and Central Europe is a major competitive advantage. The access to the Black Sea offers excellent trade opportunities, and the Danube River provides good access to Central Europe.

There is an important potential for the export of cereal products surplus on the world market, and the excellent railway infrastructure and port facilities in Constanța make this possible. In the country, there are available spaces for excess grain storage, although some still require investment for modernization, development of the handling standards and combating losses. Furthermore, there is also the potential for crop irrigation.

Despite these strengths, the sector has major weaknesses, especially as concerns the market sphere, which at the level of input offer is poorly organized, fragmented and speculative, which makes them expensive and financial resources difficult to access. Productions per national hectare are mainly due to the use of a small amount of inputs, poor agricultural technologies and management deficiencies.

The production of vegetables (including melons) in Romania has traditionally been dominated by the private sector and focused, especially, in small family farms. A large weight of vegetable production is retained at the level of farms for self-consumption, and significant quantities sold directly to consumers, most often on the peasant market.

During the period 2014-2018, according to the information recorded by the relevant ministry, the production of main vegetable species is the following: cabbage, tomatoes, onions, peppers, other vegetable species, which recorded an increase during the years researched.

The strengths of this sector are the relatively low labor costs, favorable soils and climatic conditions in large areas of Romania, which are favorable to growing vegetables. However, this sector is affected by low yields and the lack of a commercial orientation of producers. At the same time, the products quality is quite modest.

Most farmers sell their products on their own or through relatives, not using too much the system of capitalization through intermediaries. Marketing and trading associations are few in number, but have the advantage of selling larger quantities, sorted and calibrated, which provides an extra income to associated 
farmers. At the same time, by offering products through associations, the marketing costs of individual farmers can be curtailed, so that they can also find connections with supermarket chains.

The culture of oil plants (Figure 2) ranks 3rd in the classification of the value structure of the plant production by main crop groups (about 12\%). Within the European Union, Romania ranks first in sunflower production (2.9 million tons per 986,000 hectares cultivated). [13] As in the case of sunflower production, Romania holds a leading place in soybean production within the European Union.

As in the production of cereals, the oil plants production benefits from soil and climatic conditions, as well as from the strategic physical-geographical position.

Livestock production is the main beneficiary of the results within the plant sector. It has a major potential for improving food security and lowering poverty in rural areas, and the enlargement of this sector depends on the diligence for sustainable agricultural development.

The value structure of the animal production by main species and product groups (Figure 3) represents the following differences compared to each previous year during the years 2014-2018.

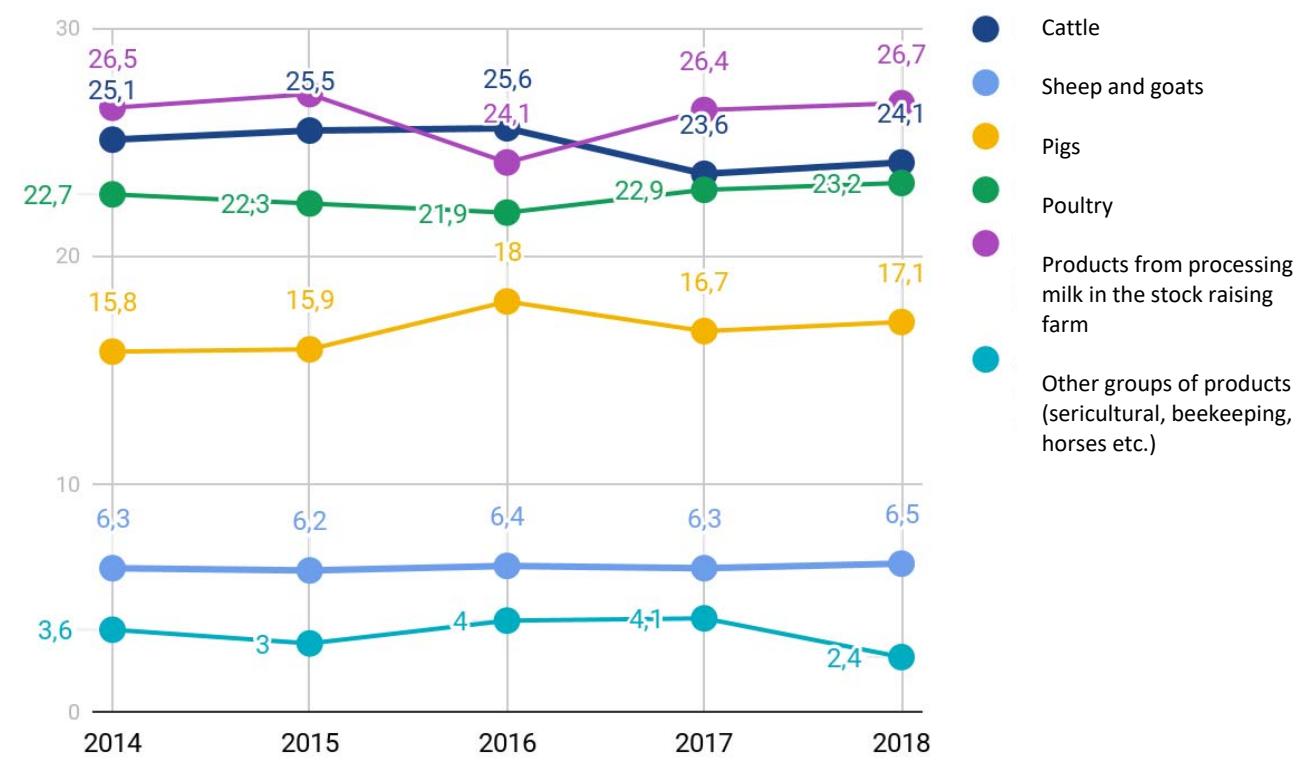

Figure 3. The value structure of the animal production by main species and product groups (20142018) (\%)

Source: Worked by the authors based on data reports by the NIS (2014-2018) [3]

According to registered reports of the National Institute of Statistics, we note that the main group of products of value to animal production is the products obtained from milk processing in the stock of animal farms, with a weight of about $26 \%$ annually during the research period, the lowest value being recorded in $2017-24.1 \%$. The following positioning of the animal production structure is: cattle (25\%), birds (22\%), pigs (16.5\%), sheep and goats (6\%), other product groups (sericulture, beekeeping, horses etc.) $(3,5 \%)$.

The sector of products acquired from milk processing in the stock raising farm in Romania is currently characterized by a small-scale production. Paying attention to milk quality is currently quite low at the farm level, both in terms of rational and hygienic collection of milk and delivery prices for processing and in its sale on the peasant market. The milk collection system is fragmented and has poor logistics and, at the same time, has shortcomings in relation to ensuring the quality analysis facilities and the cold chain existence.

According to data published by the National Institute of Statistics, we deduce that the largest amount of milk is received from cows, over 4 billion liters, followed by the production of sheep milk (over 300 million liters), milk production from goats (about 200 million liters), the line being ended with the production of milk from buffaloes (about 20 million liters). According to the estimates, the lowest milk production was obtained in 2014, when 80 factories were closed because they did not meet European Union standards, and in 2015, milk quotas were eliminated. These measures represented an increase in imports, which caused that, currently, between $20-25 \%$ of the milk used for processing comes from abroad. [13], [14]

Despite these difficulties, this sector is likely to increase competitiveness. At farm level, productivity and efficiency could be increased through healthy animal nutrition and adequate practices concerning their hygiene, measures that could increase milk quality. There will arise special opportunities for processing units, which will invest in collection centers and modern processing technologies.

The beef sector is not very different from the other meat production sectors, and production is secondary to the dairy sector. The beef production would play an important part in the development of small commercial farms, but for this there should be assigned the necessary resources to increase them. It is also 
mentionable the special potential that cattle breeding has for the pastureland systems in the mountain areas, which can also make a significant contribution within the actions related to the environment protection.

Cattle herds, total beef production intended for the market are still insufficient and unsatisfactory compared to the existing potential, the evolution of which being: the weight of cattle intended for slaughter for consumption is on average about 196.8 thousand tons, and the structure of this total beef production registering $13.5 \%$. [13], [14]

The vast majority of blockages recorded in the growth of the cattle sector are the lack of a coherent development strategy and insufficient support for the sector. The cattle sector, although it involves multifunctional activities, has also the advantage of ensuring a higher efficiency, the risk of achieving losses being diminished by the fact that both milk and meat are produced.

The poultry sector is extremely polarized: there are very few large-sized integrated units and many small individual producers. The latter produce, in particular, for self-consumption and sell the excess of products on the peasant market.

During the period 2014-2018, the evolution of total poultry production recorded a growing trend. Specifically, during this period, the weight of birds to be slaughtered for consumption was over 500 thousand tons, the largest amount was recorded in 2018 (over 600 thousand tons). The structure of total poultry production is on average $39 \%$. [13], [14]

The weak spot of this sector is that the production achieved from small producers supplies a large part of the poultry population. This supply of poultry is considered to be uneven as concerns quality and induces the risk of a series of epidemics among poultry due to poor biological security and the risk of consumer becoming ill due to low storage standards and poor hygiene during distribution.

Nevertheless, the advantage of this sector is that there are also large and integrated companies that supply the organized market. This makes it possible to perform regular controls on the observance of quality and hygiene standards among the products offered on the market, while also ensuring the necessary conditions for the creation of a highly efficient sector.

Consequently, analyzing the most important activities of the vegetable and stock raising sector (top 3 in the ranking), it can be said that Romania still has a lot to undertake in order to reach European Union standards, to be competitive with vegetable and animal products on the market international, both from the viewpoint of average production, and as concerns product quality.

Analyzing the results of the main species of plant and animal crops, we can say that Romania has very favorable soil and climatic conditions for field crops and horticulture, which creates optimal conditions for stock raising, in conditions of economic efficiency. All these aspects, as well as the advantageous geographical position and the transport facilities, can make Romania one of the main producers of agri-food products in the European Union.

\section{Strategies for sustainable rural development in Romania}

Analyzing the goals of the program, we see that the operations for the period 2014-2020 intend to stabilize the medium and longterm development of the agricultural area, respectively of the rural areas. The strategy of the National Program for Rural Development addresses the following challenges: Competitiveness, Resources, People and Society, Administration and Government. [1], [10], [15]

For overcoming these limitations and difficulties, there are envisaged to be adopted a number of priority strategic measures showing operational policies with economic and social impact favorably. Among these, we mention hereafter the most important priorities: [12]

* encouraging knowledge innovation in agriculture and rural areas;

* increasing the attractiveness of agricultural farms and performances of all types of agriculture in all regions and the promotion of innovative agricultural technologies and sustainable management of forests;

* forwarding the organization of the food chain, including the processing and trading of agricultural products, animal welfare and risk management in agriculture;

* restoration, conservation and consolidation of ecosystems which are related to agriculture and forestry;

* promoting the efficient use of resources and supporting the transition to a low-carbon emission and climate-resilient economy in the agricultural, food and forestry sectors.

In the long run, all the measures taken by this strategy refer to increasing the added value of agrifood products, increasing the yields and labor productivity in agriculture, enhancing the competitive spirit of entrepreneurs for the increase of economic activities, reducing poverty and social inclusion, reducing risks to climate change, etc. Therefore, the socio-economic aspect of rural areas must include a modern and competitive orientation.

\section{Conclusions}

The sustainable rural development of Romania during the years 2014-2018 is significant, and the effects produced are undeniable, manifested mainly by the contribution made to changes and developments 
in agriculture, diversification of ways to develop value chains of agri-food products that can be proven useful in ensuring the long-term environmental stability of this sector.

Romania has made significant efforts to harmonize technical regulations with the European standards for agri-food products, which ensure the protection of human health and the consumer. Notwithstanding, the vulnerability of this sector to natural, economic and commercial risks remains very high.

However, analyzing the main outcomes by plant and animal species, we conclude that Romania has the advantage of favorable pedo-climatic conditions in growing plant products, which creates optimal conditions for enhancing the stock raising production. proposed:

In order to grow the rural susteinable development sector in Romania, the following can be

\$ supporting human capital;

\& development of the educational and agricultural sector;

* removing the bureaucratization of the systematization framework of the entrepreneurial profession;

* backing up foreign direct investment in rural development;

4 improvement of roads and reducing the excessive costs of installing communal infrastructure;

* capitalizing the public - private partnerships, etc.

In conclusion, the proposals concerning sustainable rural development are a challenge for the local and regional public authorities, especially there is not a universal model valid at global level to record success for any country. Nevertheless, it is essential for each country to be aware of the advantages presented by the sustainable rural development over economic development and the stability of the various directions of action for the purpose of developing this sector, at the same time making also use of the competitive advantages that could certainly contribute to improving the current situation.

\section{References}

1. Comisia Europeană, „Comunicare a comisiei, Europa 2020, O strategie europeană pentru o creștere inteligentă, ecologică și favorabilă incluziunii", Bruxelles, 2010; Disponibil la https://www.mae.ro /sites/default/files/file/Europa2021/Strategia_Europa_2020.pdf, accesat la data 13.07.2020;

2. Guvernul României, „Ordonanța Nr. 53 din 16 august 2002 privind Statutul-cadru al unității administrativ-teritoriale”, 2002; Disponibil la http://www.cdep.ro/pls/legis/, accesat la data 11.07.2020;

3. Institutul Național de Statistică, „Anuarul statistic al României”, (2014-2018); Disponibil la http://www.insse.ro/cms/ro/content /anuarele-statistice-ale-rom\%C3\%A2niei, accesat la data 11.07.2020;

4. Institutul Național de Statistică, „România în cifre” (2014-2018), România, București; Disponibil la http://www.insse.ro, accesat la data 15.07.2020;

5. Institutul Național de Statistică, „Tendințe sociale”, România, București, (2014-2018); Disponibil la http://www.insse.ro, accesat la data 11.07.2020.

6. Institutul Național de Statistică, „Forța de ocupare în România: ocupare și șomaj”, România, București, 2019, p. 24; Disponibil la http://www.insse.ro/cms/sites/default/files/field/publ icatii/forta_de_munca_in_romania_ocupare_si_somaj_2018.pdf, accesat la data 20.07.2020;

7. $\quad$ Ministerul Agriculturii și Dezvoltării Rurale, Direcția Generală de Dezvoltare Rurală, „Programul Național de dezvoltare rurală 20142020" Disponibil la https://www.madr.ro /docs/dezvoltare-rurala/2019/PNDR-2014-2020-versiunea-IX-aprobata-23-ianuarie2019.pdf, accesat la data 11.07.2020;

8. Ministerul Agriculturii și Dezvoltării Rurale, Autoritatea de management pentru PNDR, „Analiza socio-economică în perspectiva dezvoltării rurale 2014-2020"; Disponibil la http://www.madr.ro/docs/dezvoltare-rurala/programare-2014-2020/analizadezvoltarii-rurale-agricultura-iulie-2013.pdf, accesat la data 30.07.2020;

9. Ministerul Mediului, Apelor și Pădurilor, Direcția Generală Evaluare Impact și Controlul Poluării, „Avizului pentru programul Național de Dezvoltare Rurală 2014-2020", 2015; Disponibil la http://www.mmediu.ro/app/webroot/uploads/files/2017- 0130_aviz_PNDR_2014-2020.PDF, accesat la data 10.08.2020;

10. Ministerul Agriculturii și Dezvoltării Rurale, „Strategia de dezvoltare rurală a României, 2014-2020”; Disponibil la http://www.madr.ro/docs/dezvoltare-rurala/programare-2014-2020/strategia-de-dezvoltare-rurala-2014-2020-versiunea-Inov2013-update.pdf, accesat la data 20.08.2020;

11. Popovici E., Bălteanu D., Kucsicsa Gh., „Utilizarea terenurilor și dezvoltarea actuală a agriculturii”, Editura Academiei Române, București, 2016

12. „Strategia Programului Național de Dezvoltare Rurală 2014-2020”, accesat la data 10.08.2020;

13. https://www.agro.basf.ro

14. http://www.madr.ro

15. Analysis of ERDF support for inclusive growth in the 2014-2020 programming period, Final report, European Commission, DirectorateGeneral for Regional and Urban Policy, Unit 03 Inclusive Growth, Urban and Territorial Development May 2018. 